ISSN 2657-327X

\title{
A landscape embroiled: Experience of nature through experience of art 1
}

\section{Paula Milczarczyk}

(Faculty of Social Sciences; University of Gdańsk)

\begin{abstract}
:
The article sets out with the theory of "aesthetics of reality" (created by Maria Gołaszewska) and its related method of transferring artistic structures onto non-artistic reality. The resulting construct, which is dubbed a para-artistic structure, becomes the theoretical basis for the aesthetic experience of nature. The so-called "formalization" - a procedure which consists in inserting nature into artistic frameworksmakes natural phenomena acquire a pretense of artwork. Nature as a picture becomes a landscape, while terms connected with the aesthetics of nature gain artistic qualities, enabling use of such notions as picturesque or kitsch. The methodological proposal by Gołaszewska is subsequently compared with the critical perspective of environmental aesthetics.
\end{abstract}

Key words:

art, environmental aesthetics, landscape, structuralism

1.

A sunset is an intellectual phenomenon

(Pessoa 2017, 121)

Had the beauty of London fog existed before William Turner?2 From the standpoint of the structuralistically oriented aesthetics of reality by Maria Gołaszewska,

1 This article is an extended version of part of the following text: Paula Milczarczyk, "Estetyka codzienności. O relacji

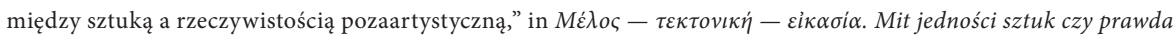
wyobraźni? Architektura, muzyka i sztuki plastyczne jako sztuki siostrzane, eds. Ryszard Kasperowicz and Aleksandra Skrabek. Lublin: Galeria Labirynt i Autorzy, 2018, 113-27.

2 The anecdote according to which it was Turner who "taught" the English to notice the beauty of London fog fueled the so-called Oscar Wilde paradox, which may be encapsulated in his "Life imitates Art far more than Art imitates Life." The question of how deeply our experience of the beauty of nature is conditioned by works of art is elaborated on by Wilde in the essay entitled The Decay of Lying (2000): "Things are because we see them, and what we see, and how we 
a work of art (including its immanent cognitive schema) provides ready-made patterns of perceiving extra-artistic reality, and thus plays a substantial role in the process of approaching nature in the aesthetic dimension. Gołaszewska's conception is founded on the premise that two domains-the world of art and the extraartistic world-overlap and create a shared realm which, embedded in the framework of structural community, generates a new quality (the intellectual construct emerging as a result is referred to by the philosopher as a para-artistic structure). Gołaszewska justifies the structural approach by finding that "it is in the structures of objects and phenomena that one can and should seek the most significant, relevant differences and similarities between art and those objects, events and phenomena which by definition do not belong to art but do possess aesthetic qualities. "... At any rate, structure provides us with a basic category because, as it seems, taking into account the internal relationships between elements distinguished within an entire system permits the most thorough elucidation concerning the aesthetic value of extra-artistic facts" (Gołaszewska 1984a, 80).

Gołaszewska's "aesthetics of reality" may be described as a theory of art discovered in the world which applies when the artistic is chanced upon in the extraartistic sphere of reality, in other words, when "an object is extrapolated from the everyday world, segregated, and framed.... Art is claimed where none was intended.... What found art does do is center our attention on an object or event in a way that resembles the intense focus we give to things designated as art by an artist, an institution, or the art world" (Berleant 2010, 179). ${ }^{3}$

Drawing on the paradigm of the so-called aesthetic situationism conceived by Gołaszewska, one could classify that type of experience as an "incomplete aesthetic situation": when a creation exists but the creator cannot be identified, and thus, when that quasi-artistic dimension which is intellectually extracted from the structure of an object (or broadly: fact) has not been consciously planned or designed by anyone. It may be said that in the structure of the phenomenon discussed by the philosopher, the "creative" and the entitative aspect overlap, while the prime case in point is the beauty of natural forms, concerning which Roger Caillois (1963) observes-in the context of his theory of generalized aesthetics-that the origin of this kind of form is properly assigned to chance, even though such forms owe their appearance to a welter of determining causes. At the same time, he believes that the welter that determines things from the very outset is thoroughly random. Thus,

see it, depends on the arts that have influenced us. To look at a thing is very different from seeing a thing. One does not see anything until one sees its beauty. Then, and then only, does it come into existence. At present, people see fogs, not because there are fogs, but because poets and painters have taught them the mysterious loveliness of such effects. There may have been fogs for centuries in London. I dare say there were. But no one saw them, and so we do not know anything about them. They did not exist till Art had invented them" (233).

3 This is how Arnold Berleant characterizes the transformation of a random object into an artistic objet trouvé. In that fragment, one should pay particular attention to the motif of the so-called "framing" of extra-artistic reality, which is also encountered in Gołaszewska, especially in the context of the aesthetic experience of landscape. 
he claims that forms born of life have not been created by anyone, and they seem to be their own sculptor. ${ }^{4}$ Gołaszewska's approach also operates under the assumption that by seeking and revealing something else in an object than the object itself, we arrive at a peculiar "surplus of meaning" which causes reality to cease being a purely physical entity in our eyes, and becomes "meaningful." 5 To Nicolai Hartman, that type of aesthetic experience (including the experience of landscape) constitutes a "second-order seeing" which is enacted when the other becomes active; the first is directed upon what is really present to the senses, the second upon this other thing, which exists only "for" us, the observers. For Hartman, this other thing is not projected into the first randomly, rather it is clearly dependent upon what is seen (Hartmann 1985). ${ }^{6}$ According to Gołaszewska, that "additional meaning" is revealed when a sensorially given, extra-artistic object (fact) is subjected to the intellectual procedure of artistic structuration-that is, undergoes formalization by being enclosed within frames, or a network of art-related notions are imposed on it. ${ }^{7}$ It is thus a singular case "when artistic structures (created as part of artistic activity) are transferred onto actual reality and prove applicable to that reality. In such instances, we may speak of para-artistic structures, because no artistic object nor a work of art is produced at the time, but the existing objects are treated in the manner of artworks" (Gołaszewska 1984a, 82). Significantly enough, those structures should be seen solely in analogy to the arrangements occurring in art (hence the prefix "para" which the philosopher consistently employs), as due to the procedure an extra-artistic object (fact) - as she often stresses-only resembles a work of art "when reality is inscribed into artistic (i.e., para-artistic) structures, the object continues to be what it is: an object of the real world; it does not become an artwork exclusively. The only thing that changes is the perspective from which it is approached, followed by a shift of the mode of its belonging to the human world" (Gołaszewska 1984a, 90; emphasis added).

4 In this context, one begins to see a deeper sense in the title of the first photo book published in the mid-19th century, Fox Talbot's The Pencil of Nature, echoing a concept of nature which "draws itself." See Macnaghten and Urry (1998).

5 "Nature starts becoming an aesthetic object in our eyes only when we approach it as meaningful, when we impart a sense to it, when it affects us as if it harboured more than the purely physical existence would suggest" (Gołaszewska 1984b, 110).

6 A similar approach is suggested by Adorno $(2004,92)$ : "What is beautiful in nature is what appears to be more than what is literally there."

7 That singular "artistic seeing" of reality is something artists fairly often admit to. In this respect, see the interesting study on Dzienniki (Diaries) by Maria Dąbrowska, where we read that "on several occasions in Dzienniki, one encounters notes stating explicitly that their author views external reality as ready-made visual compositions ... : 'ruins seen through the window look like a futurist's landscape,' 'the beautiful village of Hel, as if cut out from an old Dutch painting,' 'entering the tremendous forest, with trees from Andriolli's etchings,' 'the yard and the house-like the mood in Linke's painting, laced with Goya”' (Bieńkowska and Umińska-Tytoń 2016, 45). 
Consequently, the presumed structural community of both those realms (the artistic and the extra-artistic worlds) by no means makes them identical. ${ }^{8}$ The construct described by Gołaszewska-the para-artistic structure-is therefore a practical notional tool serving to describe a phenomenon which could be labelled an epistemological "by-product" of the mimetically oriented artistic practice because, as it turns out, the extra-artistic reality, subjected to fragmentation, formalized and enclosed "within the frames" of art, subsequently begins to function (in that formalized shape) as a pattern of perceiving reality. ${ }^{9}$ Consequently, when contemplating a wide expanse of landscape, for instance, one unwittingly looks for structures known from painterly compositions (hence the Polish adjective malowniczy derived from the verb malować-to paint, and the $18^{\text {th }}$-century category of the picturesque). The dependencies between art and reality prove to be reciprocal (in other words, interdependencies are at play); therefore, "since the earliest periods art has conceptualized in twofold fashion: as a technical dexterity and as a means of mirroring the world. The view that art imitates nature was contrasted with the view that 'nature imitates art,' meaning that it was only thanks to the emergence of specific structures and values in art ... that the human is capable of discerning those qualities and structures in nature" (Gołaszewska 1984b, 12).

In the context of his aesthetic theory of imagination, Joseph Addison (1712) went as far as making the paradoxical claim that "we find the Works of Nature still more pleasant, the more they resemble those of Art" (Addison 1712, 189).10

\section{2.}

The pure mornings and the gentle, mist-filled sunsets stirred in me the contempt I have for kitsch

(Hłasko 1957, 9)

The $19^{\text {th }}$-century aphorism of "nature imitating art" has its philosophical underpinning in the idealistic aesthetic reflection of G. W. F. Hegel. In fact, Hegelian thought brings an end to the grand tradition in which the beauty of nature was a paragon for the beauty of art, while the latter was merely an act of imitating

8 Here, the extra-artistic world is not construed along the romantic lines of a "total work of art," as from the standpoint of logic that would be a categorial error consisting in a confusion of two separate ontological categories. Moreover, Gołaszewska's model does not bear traits of panaestheticism, because the approach she describes does not rely on an absolute and permanent perception of the world in the aesthetic manner but merely on constant readiness to adopt such an attitude.

9 According to Derek Gregory, the mechanism of pictorial fragmentation of the world is rooted in the 18th-century concept of "world-as-exhibition" which, following the establishment of geography as a scientific discipline, yielded a new type of visualization of reality ("picturing the world"). See Macnaghten and Urry (1998, 121).

10 On the other hand, Addison (1712) underlines that "if we consider the Works of Nature and Art, as they are qualified to entertain the Imagination, we shall find the last very defective, in Comparison of the former; for though they may sometimes appear as Beautiful or Strange, they can have nothing in them of that Vastness and Immensity" (189). 
that unsurpassable ideal. The conceptions of the German philosopher inaugurate an approach which presumes that the beauty of nature does not exist in itself (unfolding only in the form of artistic representation); as a result, the "aesthetics of nature" is exposed as a peculiar hoax (Morawski 1985, 202). A painterly landscape, Hegel $(2010,29)$ writes, "this work of the spirit acquires a higher rank than the mere natural landscape. For everything spiritual is better than any product of nature." 11 Hegel's view of the relationship linking those two spheres of reality is resumed in the aesthetic deliberations of Stefan Morawski. Dividing values into aesthetic (a narrow field of values associated with contact with nature) and artistic ones (a broad field of experiencing art), Morawski saw the "falsity" of pre-Hegelian premises of aesthetics in the error of identifying the sources of values with their measure (Morawski 1985, 203). Based on a theory of phases of aesthetic experience, Morawski concluded that nature is revealed as an aesthetic object only when it is subjected to a process of "culturation" (Morawski 1985, 201).12 Thus, exposure to artworks not only determines the mode in which the beauty of nature is experienced, but also enables the experience of aesthetically valent qualities in nature in general. The relationship between nature and the artwork which imitates it was conceived in even more radical terms-as a relation that betrayed traits of violence-by Theodor W. Adorno (2004, 81), according to whom "[the] concept of natural beauty rubs on a wound, and little is needed to prompt one to associate this wound with the violence that the artwork-a pure artifact-inflicts on nature."13 The very proclivity for aestheticization of nature (its apprehension as an aesthetic object) should be associated with the desire for its subjugation ("social mutilation"), while the tools enabling the human to dominate nature are to be sought in Adorno's opinion on the visual faculty: "The 'How beautiful!' at the sight of a landscape insults its mute language and reduces its beauty; appearing nature wants silence" (Adorno 2004, 90). As Agnieszka Rejniak-Majewska notes, the violence here results from the very process of objectivization from the attempt to embed it into a form; on the other hand, the act of mimetic iteration might also possess a liberating potential (Rejniak-Majewska 2014, 57). ${ }^{14}$ In special instances, a "happy

11 Hegel's idealistic views not only went against romantic aesthetics but, above all, opposed the premises of the 18th-century empirical aesthetics championed by David Hume and Anthony A. Shaftsbury, among others (Frydryczak 20082009, 44).

12 Drawing on the findings of Joachim Ritter, Beata Frydryczak (2008-2009, 49) observes that the notion of landscape itself is an invention of the modern era: the nature that philosophy and science approached in notional terms was supplanted by the eye-witnessed landscape (seen via a "panoramic view"), which made it possible to include nature in the scope of aesthetic questions.

13 Adorno's approach is corroborated by cultural critic Camille Paglia, who finds that "there is, I must insist, nothing beautiful in nature. Nature is a primal power, coarse and turbulent. Beauty is our weapon against nature" (Quoted in Macnaghten and Urry 1998, 113).

14 In its superior-quality output, art "constitutes violence" but also manages to "neutralize" it; also, it comes closer to nature thanks to contemplative thought, where it negates the imposed ascendancy of the human over nature (RejniakMajewska 2014, 57-59). 
reconciliation" may ensue, momentary though it is. As an example, Adorno cites Corot's painting (Adorno 2004, 88).

The process of "culturation" of the experience of nature, which manifests, for instance, in the human penchant for approaching nature in a manner one approaches a work of art (the mechanism of plotting artistic structures over extra-artistic reality, described by Gołaszewska) seems to be reaching its termination. The shift, whose origins should be traced back to the Adornoian postulation for a return to the beauty of nature that was not mediated by art, may be described as augmented aesthetics, one which transcends the narrow approach that held sway since Hegel and confined the scope of aesthetics to the work of art..$^{15}$ The conviction that reality harbors a much broader aesthetic potential than artistic beauty is reflected in such discourses as aesthetics of everyday life, soma-aesthetics, and eco-aesthetics. Based on vindication of the mundane experience (and change of approach to experience as such) or greater emphasis on the so-called inferior senses (touch, smell, taste) in everyday life, contemporary aesthetic thought empowers a broad approach to the phenomenon of aestheticity, by virtue of which the term can be applied to various manifestations of reality. ${ }^{16}$ In the wake of those transformations, the aesthetic study of nature obtains a new form, with eco- or environmental aesthetics becoming ever more widespread paradigms. The new perspective in research radically rejects such notional categories as "formalization" and "enframing" with their associated mechanism of artwork-like perception of nature. Being based on extremely anthropocentric conceptions, they are considered instruments of oppressive fragmentation which inevitably leads to objectification of nature. ${ }^{17}$ This entails the dangers of reductive approaches to nature which, erroneously, demote living nature to an immobile image, to pure visuality, an inanimate object, which Adorno had already commented on in his Aesthetic Theory. What is more, the approach permits use of contradictory terminologies with respect to nature, such as the notion of kitsch, which became so well-established in art theory. ${ }^{18}$ In this context, Gołaszewska refers to the view of the Giewont mountain, "the mountains, looked at as a 'beautiful landscape' on the one hand, promptly become 'kitschy' or 'boring' (as it sometimes happens with the view of the Giewont seen

15 As Gernot Böhme (2002) observes, in his "reclamation" of a broad scope of interest for aesthetics, Adorno still perpetuates the traditional divisions, where nature functions (in the bourgeois fashion) as a world apart. For Böhme, nature and the human make up an indivisible union fused by corporeality.

16 This evinces a return to the original, broad notion of aesthetics as a theory of sensory perception - as envisioned by Alexander Gottlieb Baumgarten. The approach is advocated by, among others, Böhme (2002).

17 The phenomenon had manifested already in the 19th-century tourism-driven perception of nature as scenery (decoration), with the simultaneous inundation of painterly landscapes and postcards, which triggered the bourgeois idealization of nature. The latter continues today, with the substantial contribution of the mass media and tourist industry.

18 See Rogucki (2015). As for nature perceived in the categories of kitsch, Rogucki $(2015,10)$ makes an interesting observation: "The kitsch complication gives rise to a paradox which in a way seals its small victory: the kitsch claims to enact beauty, while an adherent of high art will respond by stating that beauty is tantamount to kitsch (or invariably leads to the latter)." 
from Zakopane, because it is the most typical, weighs on the landscape, and on top of that has been banalized by the numerous photographs and souvenirs)" (Gołaszewska 1984b, 106).

Adorno $(2004,94)$ noted that "great paintings and picture-postcards have in common that they have put primeval images at our fingertips," which is why "kitsch paintings have even infected sunsets."

In perceiving nature broadly (as a phenomenon), contemporary approaches relinquish the traditional divisions into the internal and the external or the subjective and the objective, directing their attention primarily to the very phenomenon of experience which permeates those dichotomous divisions. One of the chief proponents of environmental aesthetics is Arnold Berleant, who, relying on the tenets of Deweyan pragmatism, brings the communal dimension of experience to the fore, highlighting that we are not distanced with respect to the object of cognition, but we are immersed with it in a shared context: the environment (Wilkoszewska 2006, 138). Consequently, as Krystyna Wilkoszewska notes, Berleant's project may be described as aesthetics of involvement and participation, and, having such a form, it will be opposed to the post-Kantian aesthetics of distance and disinterestedness. From this perspective, the aesthetic experience of environment (understood as a network of relationships and links) is an integrated experience, engaging the spiritual and the corporal faculties of the human, who perceives themselves in a unity with what is experienced. The aesthetic experience regains its directness as the human ceases to resort to anchoring their experience in prefabricated schemata (such as the structure of artwork) because, as Böhme (2002) observes, this is what distinguishes aesthetics of nature from ecological aesthetics. As a result, nature as an aesthetic object is something which exists of itself, and moves one by virtue of its autonomous existence. Interestingly enough, a similar approach to nature (advancing a radical anti-aesthetic variant) had already been suggested in 1985 by Stefan Morawski, who wrote as follows: "If, in turn, delight is called forth by the luscious greenery of a meadow and the abundant colors of its flowers, by the serene blackness and thickness of a forest, enhanced by the song of birds and the glimpses of sky among the trees, the sudden encounter with an expanse of inky waters, with reflections of the rising or setting sun... are precisely a counter-artistic experience; a kind of polysensory fascination or authentic holidaying" (Morawski 1985, 204).

In what was a radical contradiction to Gołaszewska's proposal, Morawski held that a genuine experience of nature can only take place when "there is no concentration of suitably selected qualities within a demarcated, artificially organized (framed) structure; the moment and its augmented sensations are not 'arrested' in order to set apart a picture, retouch it, and imitate a painterly piece, or stylize it in the manner of a postcard" $(1985,204)$. 
According to Morawski's classification, the characteristic of the "fifth phase of aesthetic experience" is that "exposure to nature is no longer an act of viewing, contemplating, and savoring perfectly structured sensory qualities. The experience in which one then partakes is rather akin to swimming in a mountain lake, when the swimmer feels as if they were a fish" $(1985,206-7) \cdot{ }^{19}$

\section{3.}

"The landscape disturbs my thought," he said in a low voice. "It makes my reflections sway like suspension bridges in a furious current. It is beautiful and for this reason wants to be looked at."

I close my eyes and say: "You green mountain by the river, with your rocks rolling against the water, you are beautiful.

But it is not satisfied; it wants me to open my eyes to it."

(Kafka, 2012)

The opposed proposals discussed above (the para-artistic perspective of Gołaszewska and the anti-anthropocentric environmental aesthetics) provoke one to reflect on the aesthetic experience of nature (landscape) and, even more so, on the human approach to nature in general. Addressing the issue which both of the positions represent leads directly to further questions concerning the fluidity of the boundaries between artistic and extra-artistic reality, the relationship which joins aesthetics with ethics, the shape which aesthetic education should adopt (education through aesthetics), as well as the democratization and elitization of aesthetic experience. ${ }^{20}$ These questions have the potential to drive the reflection on, possibly resulting in a "middle-ground perspective" which would combine the two proposals. Therefore, I leave the question of whether landscape "wishes to be looked at" open.

\section{References:}

Addison, Joseph. 1712. "On Pleasure of the Imagination." Spectator 414.

Adorno, Theodor W. 2004. Aesthetic Theory. Translated by Robert Hullot-Kernor, edited by Gretel Adorno and Rolf Tiedermann. London: Continuum.

19 It may be worthwhile to note that the "aquatic" metaphor underscoring the shared aspect of experience in which the dividing line between the subject and the object is blurred would recur almost 20 years later in an essay by Berleant (2005).

20 Considering the two suggested approaches, it might seem the Gołaszewska's displays certain elitist traits, since the cultural competence of the viewer, including, for instance, knowledge of art history, is an inseparable element of the para-artistic structuration of nature. On the other hand, it may be noted that the "painterly" visions of nature are mass produced today chiefly by popular media-advertisement, the tourist industry, or design (gadgets). It would therefore seem that the experience of landscape that does not become entangled in structured visions of this kind is an elite experience. 
Berleant, Arnold. 2005. "The World from the Water." In Aesthetics and Environment: Variations on a Theme, 94-109. Aldershot: Ashgate.

Berleant, Arnold. 2011. Sensibility and Sense: The Aesthetic Transformation of the Human World. Luton: Andrews UK.

Bieńkowska, Danuta and Elżbieta Umińska-Tytoń. 2016. "Między słowem, obrazem a muzyką, czyli o integralności sztuk w Dziennikach Marii Dąbrowskiej" ["Between Word, Depiction, and Music: On the Integrality of Arts in Maria Dąbrowska's Journals"]. Studia Językoznawcze 15: 39-50.

Böhme, Gernot. 2002. Filozofia i estetyka przyrody w dobie kryzysu środowiska naturalnego [Philosophy and Aesthetics of Nature in the Era of the Environmental Crisis]. Translated by Jarosław Merecki. Warsaw: Oficyna Naukowa.

Caillois, Roger. 1963. "Estetyka uogólniona" ["Generalized Aesthetics"]. Translated by Jerzy Lisowski. Twórczość 10: 40-56.

Frydryczak, Beata. 2008-2009. "Estetyka przyrody: nowe pojmowanie natury" ["Aesthetics of Nature: A New Understanding of Nature"]. Estetyka i Krytyka 15/16: 41-55.

Gołaszewska, Maria. 1984a. Estetyka rzeczywistości [Aesthetics of Reality]. Warsaw: Instytut Wydawniczy PAX.

Gołaszewska, Maria. 1984b. Zarys estetyki [An Outline of Aesthetics]. Warsaw: PWN.

Hartmann, Nicolai. 1985. "Sposób istnienia i struktura przedmiotu estetycznego" ["The Manner of Existing and the Structure of an Aesthetic Object"]. Translated by Janusz Krupiński. In Estetyka w świecie [Aesthetics in the World], edited by Maria Gołaszewska, 267-71. Kraków: Wydawnictwo Uniwersytetu Jagiellońskiego.

Hegel, Georg Wilhelm Friedrich. 2010. Lectures on Fine Arts. Translated by Thomas M. Knox. Oxford: Clarendon Press.

Hłasko, Marek. 1957. "Dom mojej matki" ["My Mother's House"]. In Pierwszy krok w chmurach [First Step in the Clouds], 5-11. Warsaw: Czytelnik.

Kafka, Franz. 2012. "Description of a Struggle." In Complete Stories, edited by Nahum H. Glatzer. New York: Schocken Books. E-book.

Macnaghten, Phil and John Urry. 2005. Alternatywne przyrody. Nowe myślenie o przyrodzie i spoteczeństwie [Contested Natures]. Translated by Bogdan Baran. Warsaw: Scholar.

Macnaghten, Phil and John Urry. 1998. Contested Natures. London: SAGE.

Morawski, Stefan. 1985. "O estetycznym i pozaestetycznym przeżyciu wobec natury (czyli o ucieczce od życia albo powrocie do źródet)" ["On an Aesthetic Experience in front of Nature (On an Escape from Life or a Return to Sources)"]. In Na zakręcie. Od sztuki do po-sztuki [On the Curve: From Art to Post-Art], 200-09. Kraków: Wydawnictwo Literackie.

Pessoa, Fernando. 2017. The Book of Disquiet. Translated by Margaret Jull Costa, edited by Jeronimo Pizarro. New York: New Directions. E-book.

Rejniak-Majewska, Agnieszka. 2014. Puste miejsce po krytyce? Modernizm i materialistyczna rewizja autonomii sztuki [Empty Space After Critique? Modernism and Materialist Revision of the Autonomy of Art]. Łódź: Officyna.

Rogucki, Jacek. 2015. "Kłamstwo kiczu" ["The Lie of Kitsch"]. Kultura—Spoteczeństwo-Edukacja 2: 101-10. 
Wilde, Oscar. 1989. "The Decay of Lying." In The Major Works, edited by Isobel Murray, 215-39. Oxford: Oxford University Press.

Wilkoszewska, Krystyna. 2006. "Problem eko-estetyki" ["The Question of Eco-Aesthetics"]. Diametros 9: 136-42. 